\title{
Opinion
}

\section{Tackling Inadequate Pharmaceutical Services in Africa: Options for Public Health Action}

\author{
Babatunde Omilola, PhD; N'doh A. Sanogo, PhD* \\ Public Health, Security and Nutrition Division, The African Development Bank Group, Avenue Joseph Anoma, 0 I BP I387 Abidjan 0I, Côte d'Ivoire \\ "Corresponding author \\ N'doh A. Sanogo, PhD \\ Consultant for the Public Health, Security and Nutrition Division, The African Development Bank Group,Avenue Joseph Anoma, 0 I BP I387 Abidjan 0I, \\ Côte d'Ivoire; E-mail: n.sanogo@afdb.org
}

\section{Article information}

Received: February 12 ${ }^{\text {th }}, 2020$; Revised: March $3^{\text {rd }}, 2020$; Accepted: March $3^{\text {rd }}, 2020$; Published: March $5^{\text {th }}, 2020$

Cite this article

Omilola B, Sanogo NA. Tackling inadequate pharmaceutical services in Africa:options for public health action. Public Health Open J. 2020; 5(I): 17-19. doi: $10.17|40 / \mathrm{PHOJ}-5-14|$

\section{PROBLEM STATEMENT}

$\mathrm{T}_{\mathrm{o}}^{\mathrm{he}}$ he present document aims to present challenges and opportunities to support pharmaceutical industry in Africa. The proliferation of fake medicines in the continent is a major public health problem, with a global market worth roughly US $\$ 200$ billion and sub-Saharan Africa accounts for around $42 \%$ of the world's cases (21\% for north African and the middle East). ${ }^{1,2}$ We will first discuss the challenges for the continent in the fight against counterfeit medicines and finally the challenges and opportunities to support pharmaceutical industry in Africa.

\section{BACKGROUND}

Counterfeit medicines pose a huge threat to global public health and has become increasingly apparent over the last decade. In 2006, the Declaration of Rome was the first to acknowledge the issue of counterfeit drugs and the importance of effective coordination and cooperation at the international level for regional and national strategies to be more effective. ${ }^{1}$ According to the World Health Organization (WHO), 30\% of all medicines in Sub-Saharan Africa are counterfeit as opposed to $1 \%$ in the developed world, suggesting a link between impoverished regions and their inability to restrict counterfeit medicines. ${ }^{2}$ Indeed, the region is home to the 15 poorest countries in the world according to the human development index (HDI). Without access to medicines, Africans are susceptible to the three big killer diseases on the continent: malaria, tuberculosis and human immunodeficiency virus infection and acquired immune deficiency syndrome (HIV/AIDS). ${ }^{1,2}$ For instance, approximately 1.6 million Africans died of malaria, tuberculosis and HIV in 2015 due to lack of money to buy imported medicines combined with lack of lack of local drug production. ${ }^{2}$

\section{Challenge in Tackling the Issue of Poor Quality Medicines in Africa}

For ensuring a market free of poor quality medicines, it is first important to accentuate their identification. Limited financial and human resources, and the lack of rapid, affordable and well-adapted techniques to investigate the quality of suspicious medicines are issues for African countries and these lead to drugs regulation issues. ${ }^{3}$ After the identification of substandard medicine, rapid communication to health professionals nationally or even regionally allows relatively fast recall of the batch from the market. Unfortunately, the lack of regulation hampers communication in African countries. ${ }^{3,4}$ Surveillance is also important to identify to identify those involved in the release of substandard medicines on the market. In most African countries, criminal laws to prosecute those manufacture falsified medicines are incredibly weak or nonexistent. ${ }^{3}$ To address all these issues, the production of local drug production combine with a drug regulatory system is mandatory to ensure the quality of essential medicine.

\section{Challenges and Opportunities to Support the Pharmaceutical Industry in Africa}

The African continent accounts for only $0.7 \%$ of the pharmaceutical industry market. ${ }^{3,4}$ However, in French-speaking African countries drug imports represent more than $90 \%$ of the pharmaceutical market, growing by 6 to $10 \%$ per year, depending on the country. ${ }^{4}$ Nearly 700,000 deaths in Africa are currently due to the consumption of fake medicines. One of the main causes of the development of illicit trafficking and the marketing of fake medicines is the lack of effective and efficient control in a systemic approach. ${ }^{4}$ Between 2003 and 2013, the value of Africa's pharmaceutical industry increased by almost 5 times. The market is projected to double in value from US\$20 billion to between US\$ 40 billion 
and US\$ 60 billion by $2020{ }^{4}$ Moreover, the existence of a huge market with regional blocks (The Economic Community of West African States (ECOWAS), Economic Community of Central African States (ECCAS), etc.) is an important benefit for investments. Finally, the path of the fake drugs is prosperous which shows that if the drugs are produced, they will be sold.

Based on African Pharmaceuticals Market Report of Frost and Sullivan of 2016, the pharmaceuticals market in Africa is expected to reach a business opportunity of $\$ 45$ billion in 2020 . The main factors that underpin the future growth of Africa's market, with different impact depending on the country are (McKinsey analysis $)^{5}$ :

- Increased "genericization" (e.g. the process of becoming generic, generic drugs)

- Increased expenditure a) Increasing health investment, b) Rising consumerism - population, urbanization, middle class, Increased burden of disease

- Expanded provision: a) Expanded human resources for health $(\mathrm{HRH})$ and prescriber base, b) Evolving provider models, Increasing private sector provision

- Maturing business environment: a) Maturing business environment, Maturing regulatory environment, Improving investment climate, Reduced counterfeits, Increased confidence in generic products, Ongoing pricing pressure, b) Increasing push for local manufacturing

- Nevertheless, potential investors face several challenges that are unique to the continent ${ }^{6}$ :

- Lack of regional integration policies and consequently a broad economy need (at least by region) to attract investors and favor the private sector

- Distribution of high-quality medicationsis consistently one of the largest challenges for drug makers. Inefficient or expensive distribution increases the final price to patient, reducing volume sales and hurting family finances in the largely out-of-pocket private market for medicines.

- Low industrialization of the continent due to weak basic conditions (e.g. electricity, bad roads, etc.): Electricity and resource constraints (in some African countries are an important challenge. In fact, it may be difficult to ensure the required temperature-controlled environments in storing and distributing products. Underdeveloped infrastructure may also be ahindrance to the delivery of pharmaceutical products to those who need it most.

- Business environment: Investment versus Risk. To attract investors, the business environment must be conducive. In other words, the risks must be minimal.

\section{Possible Policysolutions Include the Following ${ }^{5,6}$ :}

- Strengthening supply chain management African governments should strengthen their supply chain management system with a logistic manager at both state \& local government level ensuring the distribution system to flow in top to bottom approach.

- African governments should also strengthen their procurement system in order to ensure hassle free procurement all the level of government by creating a procurement society to make the process even faster. For instance, governments should decentralize to the grass-roots level small purchases for the local government level.

- Focus on the growth is more than two-thirds of the continent's gross domestic product (GDP) and cumulative growth over the past decade came from just 10 of its 54 countries and $37 \%$ of all consumers in Africa are concentrated in 30 key cities

- Invest in building a strong and local sales and marketing team by analyzing its own value chain to identify opportunities for working more closely with healthcare payers and providers

- Forge local partnerships in private and public sector. Many opportunities exist from healthcare service delivery i.e. drugs, private hospitals and clinics, through support services i.e. diagnostic and laboratory services; and supply chain and logistics to health financing e.g. private insurance schemes.

\section{SUMMARY}

In sum, access to quality medicines is key to building human capital and sustainable development and improving quality of lives. It is important for Africans to elaborate on:

- Africa's pharmaceutical industrialization policies and strategies;

- Legal frameworks, regulations, standards and governance in the pharmaceutical sector;

- Production and supply of active pharmaceutical ingredients;

-Professional training and skills development in the pharmaceutical industry; and

- New opportunities to improve the pharmaceutical attractiveness of Africa.

We hope this synthesis of facts and presentation of insights will help inform governmental health policies designed to address the elimination of counterfeit medications on the African continent.

\section{DISCLAIMER |}

The article represents the author's personal opinions and not that of the Bank.

\section{CONFLICTS OF INTEREST}

The authors declare that they have no conflicts of interest. 


\section{REFERENCES}

1. World Health Organization (WHO). A bitter pill to swallow: the problem of, and solutions to, Sub-Saharan Africa's counterfeit pharmaceutical trade Web site. https://www.ghjournal.org/abitter-pill-to-swallow-the-problem-of-and-solutions-to-subsaharan-africas-counterfeit-pharmaceutical-trade/. Accessed February 11, 2020.

2. Pheage T. Dying from lack of medicines: Encouraging local production, right policies the way out Web site. https://www. un.org/africarenewal/magazine/december-2016-march-2017/ dying-lack-medicines. Accessed February 11, 2020.

3. Caillet C. Challenges in tackling the issue of poor quality medicines Web site. http://www.malaria.com/featured/medicinequality-issues. Accessed February 11, 2020.

4. Ajepe B. The opportunities and challenges for pharmaceutical supply chain in Nigeria/Africa. Clin Pharmacol Biopharm. 2015; 4(4): 55. doi: 10.4172/2167-065X.C1.012

5. Conway M, Holt T, Sabow A, Sun Y. Should sub-Saharan Africa make its own drugs? Web site. https://www.mckinsey.com/ industries/public-sector/our-insights/should-sub-saharan-africamake-its-own-drugs. Accessed February 11, 2020.

6. Mudau S. Opportunities and challenges in Africa's pharmaceutical industry Web site. https://rouseafrica.com/. Accessed February 11, 2020. 